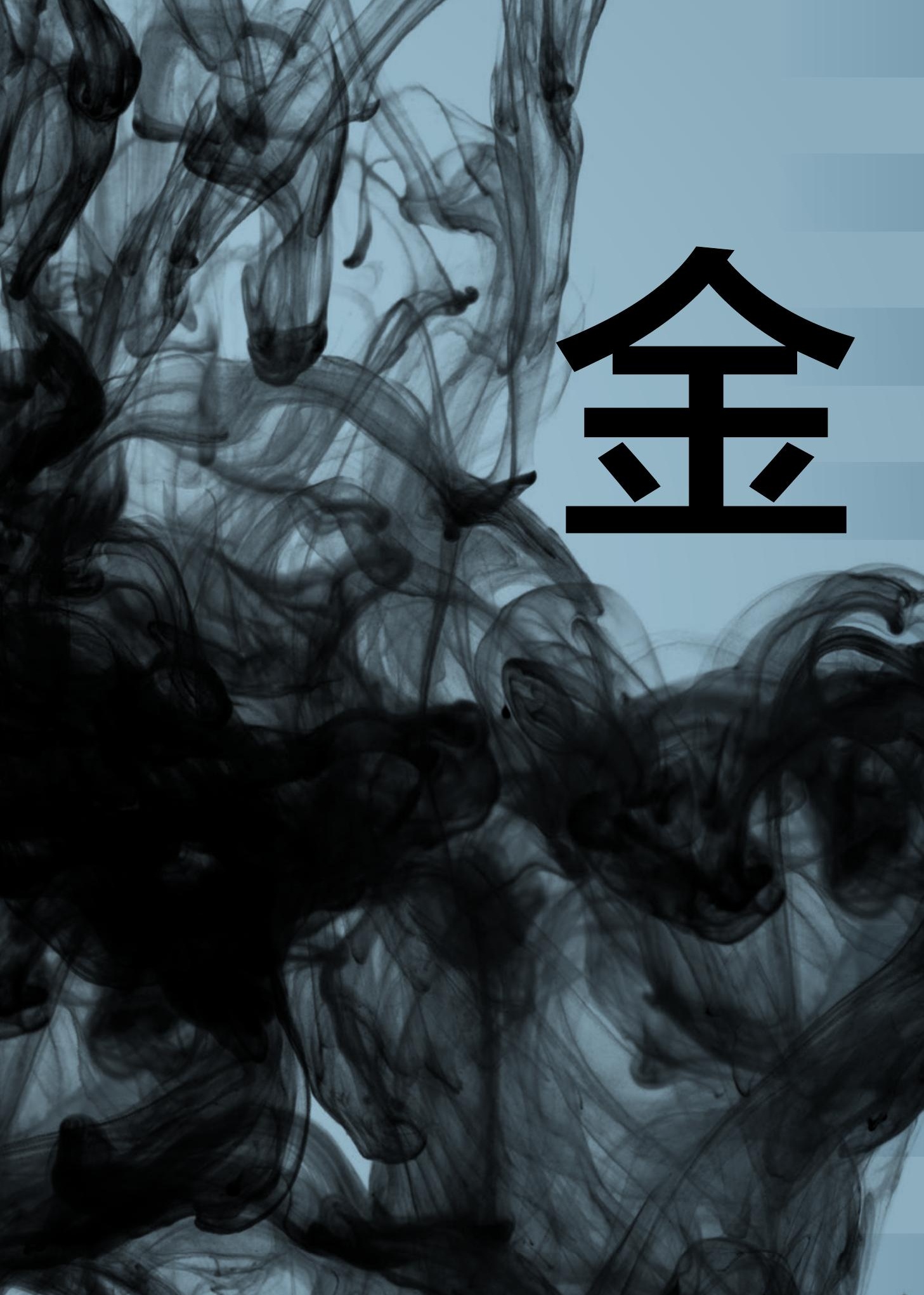




\section{BELT TIGHTENING}

\section{Rebecca Fabrizi}


IN 2015, XI JINPING continued his hyperactive diplomacy, visiting fifteen different countries within the year. He also packed in bilateral meetings with world leaders at multilateral gatherings, including with the African Union (at the ChinaAfrica Co-operation Forum in Johannesburg in December) at the United Nations General Assembly, the BRICS and SCO Summits and even during the World War II (WWII) commemorations in Moscow and Beijing. Just as in 2014, however, neither Xi nor Premier Li Keqiang visited the Middle East. 


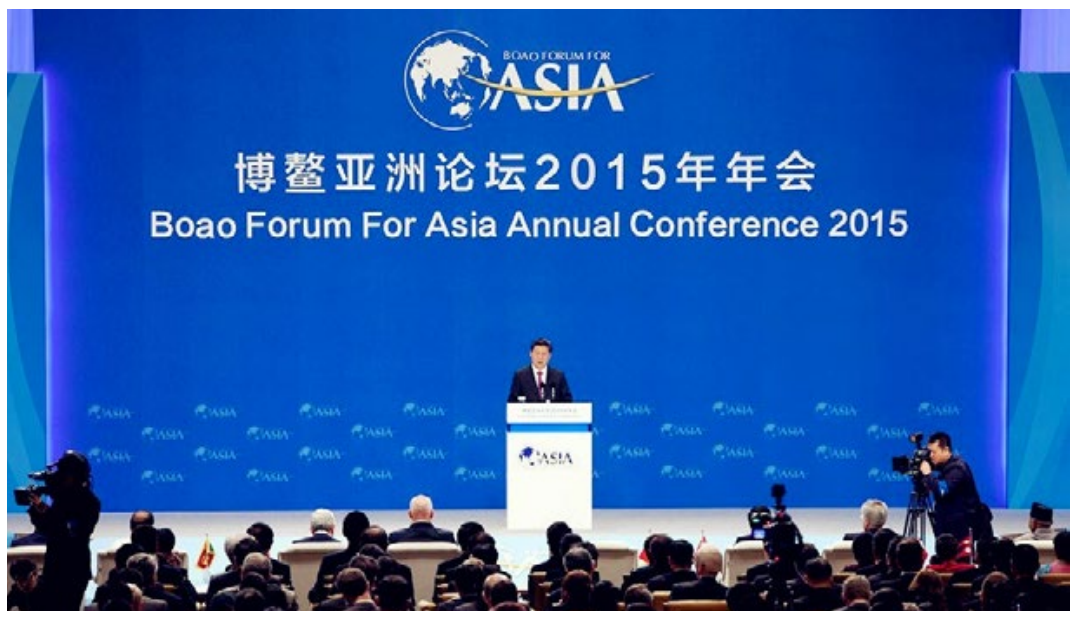

Throughout all of this frenetic foreign affairs activity, there has been a strong accent on economic diplomacy and, in particular, advancing the cause of China's 'One Belt One Road Initiative' 一带一路 (also known as 'Belt and Road Initiative' or 'OBOR') (See Forum 'One Belt One Road: International Development Finance with Chinese Characteristics', pp.244-250).

\section{Belting Up}

Xi had announced his idea for a 'Silk Road Economic Belt' and a 'Twenty-first Century Maritime Silk Road', without any details, during visits to Kazakhstan and Indonesia in September and October 2013. One month later, the Third Plenum of the Communist Party enshrined it as policy. It took until March 2015 for the State Council to publish a detailed 'Action Plan' for the policy, which had been jointly drafted by the National Development and Reform Commission (NDRC) and ministries of Commerce and Foreign Affairs. In the same month, Xi outlined the plan to an international audience at the Boao forum in Hainan Island.

The OBOR Initiative is said to have diverse aims. One is to use Beijing's large foreign exchange reserves to boost exports of domestic producers by investing in large infrastructure projects that will create demand, an idea touted for several years by domestic analysts. It may also be a way to absorb excess industrial capacity in struggling sectors such as steel. It could eventually help alleviate concern in China about over-reliance on Malacca Strait shipping, the conduit for around ninety percent of China's 
oil imports, by creating alternative trade routes. The parallel policy of creating new financial institutions such as the Asian Infrastructure Investment Bank and the New Silk Road Fund should help to bring more choice in international infrastructure financing.

Perhaps most importantly, the initiative should be a neighbourfriendly way of creating a more benign regional security and policy environment for China to get on with pursuing its domestic agenda without active or passive interference from the region. Supporters look forward to China achieving its stated goal of improved regional security and prosperity through 'common development' 共同发展. It is also a compelling soft power strategy, recalling China's rich history as a trading nation in the era of the Silk Road.

The State Council has published a dedicated website for the OBOR Initiative with maps being revised as countries express greater or lesser interest in being involved. Observers in some of the targeted countries, like India, have been skeptical about the benefits to them, even suspecting malign strategic intent. Foreign Minister Wang Yi 王毅 directly addressed

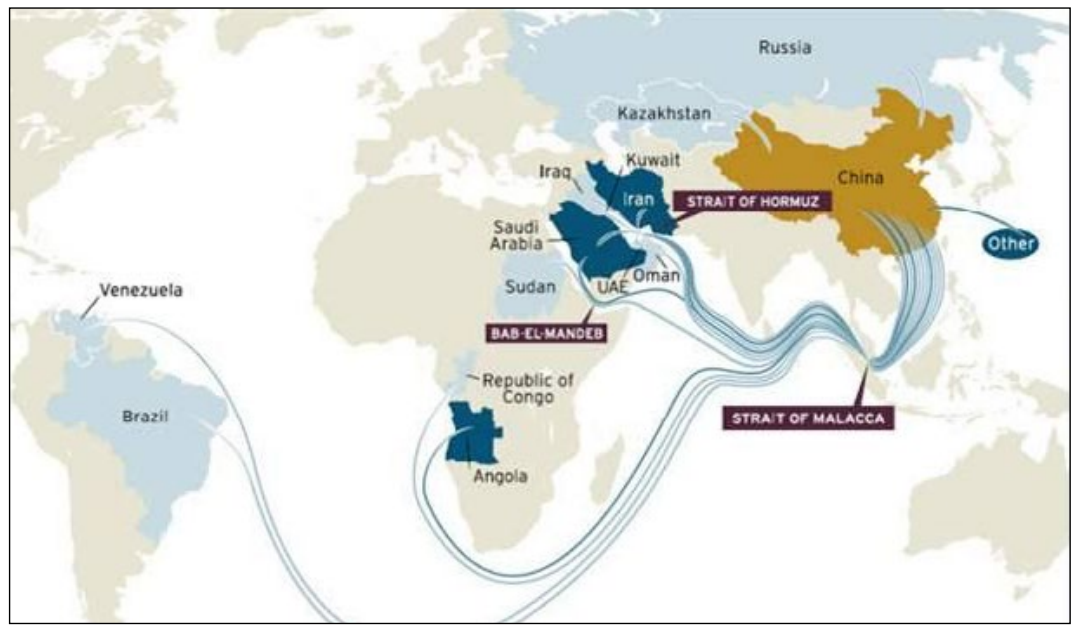




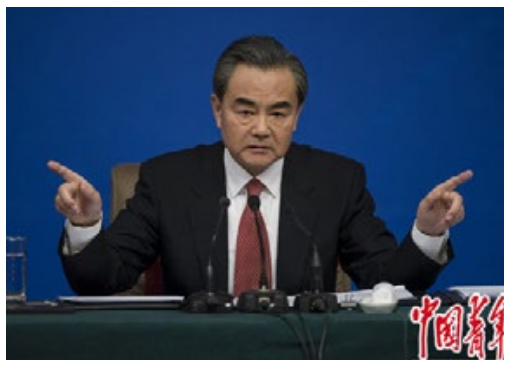

Wang Yi

Photo: cyol.com these concerns in his annual address to the press in March, when he said that the initiative was 'not a tool of geopolitics' and cautioned against viewing it through an 'outdated Cold-War mentality'.

There is no question that China is showing a high appetite for risk. This is a difficult initiative, given that it relies on Chinese enterprises making major investments when the prospect of financial return might be at best remote, and security risks could be significant. According to political scientist Xie Tao 谢蹈 of Beijing Foreign Studies University 北京外国语大学, the Chinese leadership has deliberately described the policy as an initiative, not a strategy, to avoid implying that participation will be mandatory for Chinese banks, enterprises, and other players.

If they do join in, there could be substantial risks to Chinese consulates of the kind seen in Libya in 2011 when the Chinese military had to manage its largest-ever evacuation (nearly 39,000 citizens) from a foreign country when a wave of unrest saw direct and violent attacks on Chinese oil and other firms there. The plan for OBOR is for largescale projects, likely to involve large numbers of Chinese workers. The only project so far initiated, a dam in the new 'China Pakistan Economic Corridor', involves a particularly unstable region of Pakistan. Pakistan has agreed to provide 10,000 troops and commandos for the project's security.

On the other hand, if China can contribute to growth and stability in these difficult and volatile border areas, benefit will also accrue to the US, Russia, and other regional countries and major powers.

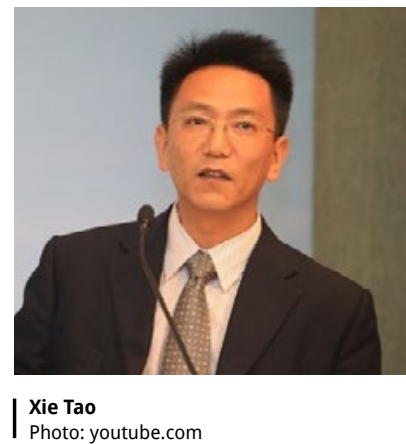


THE ISLAMIC STATE TAKES CHINESE NATIONAL HOSTAGE, by Lorand Laskai

In mid-September, the war with Islamic State (IS) arrived at China's doorstep in the form of an online advertisement: 'Chinese prisoner for sale'.

It featured a photograph of a man, Fan Jinghui 牀京辉, against a black backdrop. His face was battered and he was dressed in a yellow jumpsuit. The advertisement listed his profession as a freelance consultant and his place of birth as Beijing, China; it also published his home address.

IS held Fan Jinghui alongside a Norwegian hostage. This placed the Chinese government in a new situation. The Chinese leadership's reluctance to get in-

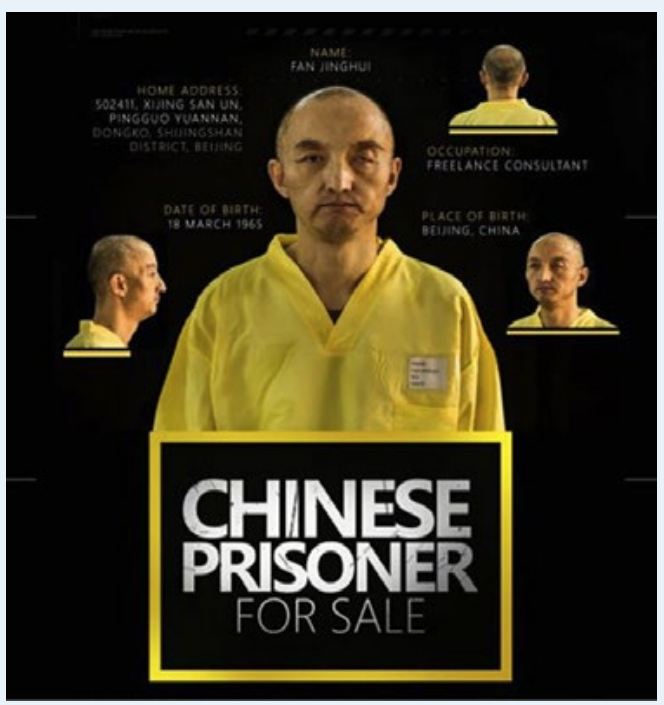

The 'advertisement' Source: ntdtv.com volved in conflicts abroad had previously sheltered its citizens from direct conflict with IS. Now the Chinese people demanded action.

While netizens called for Fan's rescue and vigorously debated the correct course of action, the Chinese government remained largely mute. Censors scrubbed the Internet of the most impassioned calls for intervention to save Fan.

On 18 November, IS executed Fan and posted photos of the execution online. There was an outpouring of grief on the Internet. Xi Jinping, in Manila for APEC, expressed sympathy towards the victim's family and vowed to 'strike against any manifestation of terrorism'. The Ministry of Foreign Affairs pledged to bring the criminals responsible to justice. Yet Chinese Internet users searching for Fan Jinghui's name on Weibo found their attempts blocked, and posts and comments calling for military intervention or questioning the government's resolve were swiftly removed.

Within the constrained media space, Chinese citizens meditated on the practical and principled dilemmas of China's evolving role in the world. 'If China was going to deploy soldiers, where would it put them?' asked one commentator. 'Russia and the US have military bases, does China? France sent an aircraft carrier, could China send its carrier to the Middle East? ... [China's] military capability should not be underestimated, but actual combat is still a weak point.' Another post on the nationalistic blog Haijiang bemoaned that ISIS doesn't care whether you're 'Western or Eastern heritage ... China cannot watch with its arms folded.' 


\section{ASIAN INFRASTRUCTURE INVESTMENT BANK AND THE TRANS-PACIFIC PARTNERSHIP}

The China-led international financial institution Asian Infrastructure Investment Bank (AIIB) formally launched on 25 December 2015 with thirty-seven regional and twenty non-regional Prospective Founding Members (PFM). The bank had on founding US $\$ 100$ billion in capital, equivalent to two-thirds of the capital of the Asian Development Bank or nearly half that of the World Bank. It is the first significant multilateral lender dominated by a developing country.

The US, which along with Japan and Canada declined to become a founding member, lobbied European countries, Australia, and South Korea not to join. Its efforts were mostly ignored. The former UK chancellor of the exchequer, George Osborne, announced Britain's application in early March, in an unusual split from the US line. Despite expressions of frustration from Washington, Australia and South Korea applied to join the bank later that same month.

The Trans-Pacific Partnership (TPP), a trade agreement signed by twelve Pacific Rim countries including the US and Japan on 4 February 2016 in New Zealand, seems like a counter-measure to the AIIB. Despite being the largest economy in the Pacific Rim, China was not involved in the negotiations. In a Washington Post article on the TPP, Obama said 'The world has changed. The rules are changing with it. The United States, not countries like China, should write them.'

\section{Global Governance}

There has been much discussion in China and abroad about the impact of a rising China on global institutions and governance. With Xi Jinping enforcing more and more restrictions on Chinese citizens' access to justice and civil liberties and freedoms (see Chapter 2 'The Fog of Law', pp.64-89), there is nervousness abroad about China's intentions with regard to international institutions.

The US government has acted on these concerns. In an embarrassing diplomatic failure, when China announced the creation of the Asian Infrastructure Investment Bank (AIIB), the US government lobbied its allies not to join despite the fact that the new bank looked set to be established according to international norms, and was a 'responsible stakeholder' response to a real and urgent need for infrastructure funding across the Asian region. The AIIB opened for business on 6 January 2016, with fifty-seven founding member countries. Many US allies signed on, including Australia, Germany, and a particularly enthusiastic United Kingdom. 


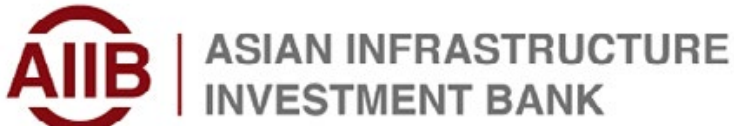

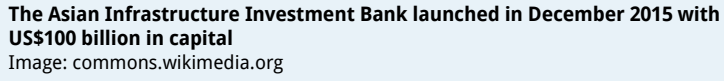

Officially, China is staying neutral. A spokesperson from China's Commerce Ministry said that China 'always keeps an open mind toward the construction of systems that are in accordance with World Trade Organisation rules and are helpful for promoting economic integration in the Asia-Pacific region'.

State media Xinhua also said that China has already demonstrated a 'deep-seated, high-standard, and comprehensive pattern of opening to foreign trade', citing new free trade agreements with South Korea and Australia and the on-going Regional Comprehensive Economic Partnership (RCEP) negotiations, a free trade agreement that would include all ten ASEAN member states, Australia, India, Japan, South Korea, and New Zealand and encompass the OBOR Initiative as well. Xinhua added that China might seek to join the TPP 'at an appropriate time'.

China is certainly having an impact on global institutions. One example from 2015 is the decision in December by the International Monetary Fund (IMF) to include the renminbi (RMB) as one of five currencies in its Special Drawing Rights basket from October 2016. This reflects the importance of the RMB to the world's trade and financial systems.

In a major speech in Seattle on 22 September 2015, Xi Jinping said:

As far as the existing international system is concerned, China has been a participant, builder, and contributor.... A great number of countries, especially developing countries, want to see a more just and equitable international system. But it doesn't mean that they want to unravel the entire system or start all over again. Rather, what they want is reform and to improve the system to keep up with the times.

Six days later, Xi addressed the UN General Assembly. There he called 'peace, development, equity, justice, democracy and freedom', the 'common values of all mankind and the lofty goals of the United Nations'. He pledged US\$1 billion over the next ten years to create a peace and 


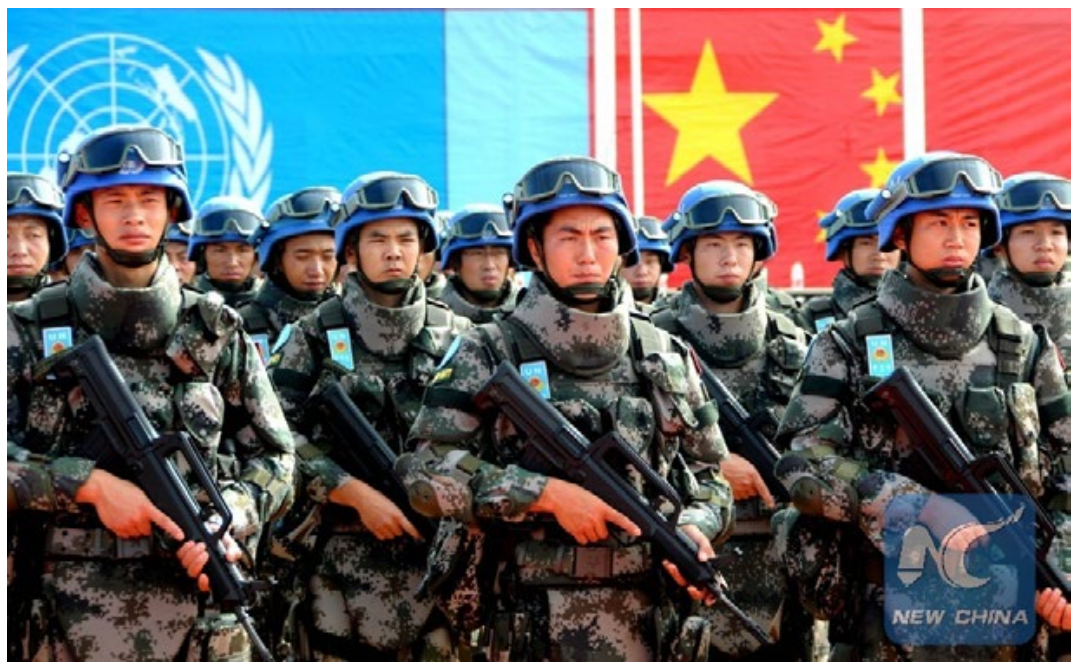

Chinese UN peacekeepers

Photo: news.xinhuanet.com

development fund to support the United Nations; the establishment of a new standby peacekeeping force of 8,000 troops; and military assistance worth US\$100 million over the next five years to the African Union for peacekeeping missions. At the UN Sustainable Development Summit the following day, he pledged a goal to invest US $\$ 12$ billion in the world's poorest countries by 2030.

China will also use its growing influence to support its own political system: such as working to reduce the ability of international organisations, like the UN, to police civil rights, freedom of expression, and justice through the work of the Human Rights Council and the visits and statements of important figures such as UN Special Rapporteurs. China continued in 2015 to take a cautious approach to the UN's Responsibility to Protect, promoting a very limited range of circumstances that would make non-consensual military intervention an appropriate course of action.

\section{Friends with Benefits}

Beijing often looks to Moscow for support in international relations, and vice versa. While Russia's relationships with Europe and the US remain strained, the potential benefits of a 'pivot East' look significant. Putin was the most important guest at the parade in Beijing to commemorate the 
seventieth anniversary of the Japanese surrender on 3 September (though not many other world leaders took up the invitation). Xi had been to Moscow in May for a similar purpose, returning to Russia for the Brazil, Russia, India, and China (BRICS) and Shanghai Co-operation Organisation (SCO) summits in July, and holding further bilateral meetings with Putin in the margins of other international events. Yet while official rhetoric speaks about the warm relationship, Chinese leaders have avoided explicitly supporting Putin's domestic politics or his actions in Ukraine. China has no interest in full-scale confrontation between Russia and the West. Indeed, Chinese analysts say in private that the Chinese leadership would prefer Putin to stop fomenting unrest in Ukraine, and fear for the sustainability of Russia's economy and society. Bilateral trade continued to stagnate in 2015.

On 6 May 2015, when Xi was visiting Moscow for the victory parade, the Rossiskaya Gazeta published an opinion piece by him titled 'Remember history, look to the future'. Chinese analysts point to one specific phrase in this article of particular significance: 'силочение - это сило, а самоизоляцуя - обессиленуе' or 'unity is strength, while self-isolation is weakness'. This was intended to remind Putin that displaying power through destructive force and alienating the international community was a path to ruin.

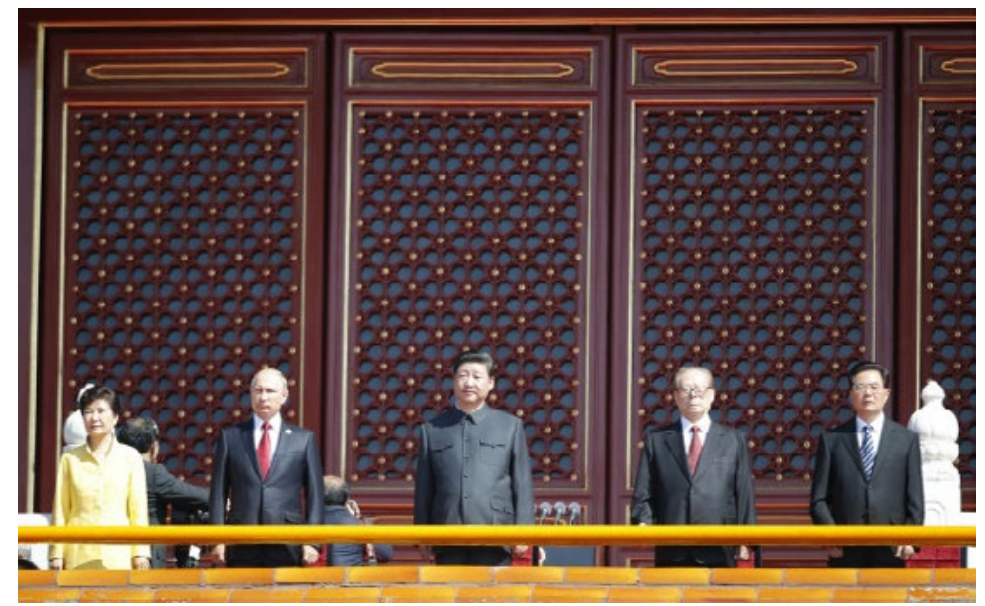

$\mathrm{Xi}$ and Putin attend the parade in Beijing to commemorate the seventieth anniversary of the 'World Anti-Facist War' (WWII)

Photo: upload.icrosschina.com 


\section{'UYGHURS MEAN MONEY, UYGHURS MEAN CASH', by Lorand Laskai}

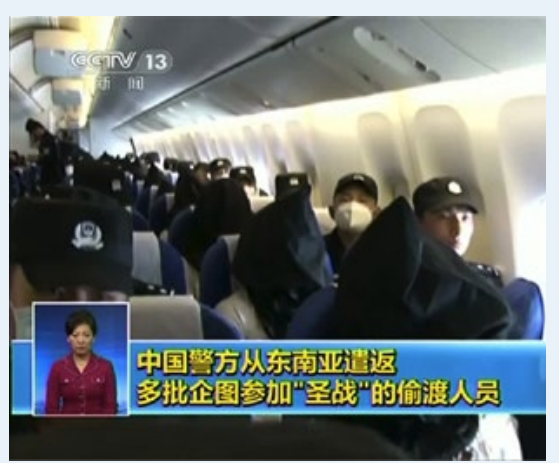

Chinese security forces escort Uyghurs suspected of travelling to join the IS from Thailand

Source: cctv.com
In mid-July, the Thai government provoked international ire when it forcibly repatriated over one hundred asylum-seeking Uyghurs back to China. Uyghurs are a Muslim Turkic languagespeaking people native to the Xinjiang Uyghur Autonymous Region, where there has been considerable unrest in recent years. In 2015, the Chinese government intensified its crackdown on Islamic dress and other religious and traditional practices in Xinjiang, adding to local grievances against Chinese rule. China has traditionally sought the return of those Uyghurs who seek refugee

status abroad, a process condemned by human rights advocates.

The repatriation of Uyghur asylum seekers to China sparked furious outrage against China in Turkey. Turkey has historically presented itself as the protector of the Uyghur people and offers asylum and identification papers to those who make it there. Anti-Chinese protesters in Ankara smashed windows and broke into the Chinese Embassy. Another hundred Uyghurs rounded-up by the Thai government in mid-July had Turkish identification papers, and were sent on to Turkey.

Turkey is a natural destination for Uyghurs fleeing the country as the Chinese government intensifies its crackdown on Islamic and traditional practices in Xinjiang, but getting there is hard. Whether they travel through Central Asia or South East Asia, the journey is harrowing and dangerous. As one refugee told Reuters in Istanbul: 'For ... traffickers, Uyghurs mean money, Uyghurs mean cash. If you are Vietnamese ... they charge $\$ 1,000$, but when you are Uyghur the price goes up five-fold, sometimes ten-fold.' He had fled after being told that his sick and imprisoned brother would not 'leave jail alive'.

Dismissive of claims of persecution, the Chinese government works hard to associate Uyghur refugees with religious extremism. The Chinese media suggested that many Uyghurs repatriated from Thailand in July have a history of extremism and that their ultimate destination was the Islamic State (IS) in Syria. One Chinese official said that many Uyghurs in Turkey had become 'cannon fodder' for IS. IS has also pushed forward the narrative, releasing a video in June 2015 featuring a eighty-year old Uyghur man who had travelled from China to join the jihad. In December, Indonesian officials foiled a terrorist plot that reportedly involved a Uyghur man who had entered Indonesia through Thailand.

The blurred line in world media between political refugees and extremists has worked in Beijing's favour. In December, Pulitzer Prize winning investigative journalist Seymour Hersh claimed that over 5,000 Uyghur 'would-be fighters' had been funnelled to Syria via Turkeyapproximately the total number of Uyghur refugees who have arrived in Turkey since 2013. 
If Xi avoids directly speaking to Russia's affairs, Putin rarely mentions Asia at all, preferring in important speeches to focus on criticising the US and the European Union. As in previous years he declined an invitation to attend the leaders meeting of the 2015 East Asia Summit.

Guiding this policy of presenting a strong friendship to the world is China's desire to have a smooth relationship with the only other permanent member of the UN Security Council that does not support US primacy in the international sphere in general, and the western Pacific in particular. Bilateral agreements and discussions on issues such as cyber security and human rights provide a counterpoint to what are usually referred to as 'universal values'. The US and China agreed on a joint cyber security pact in May 2015, for example, which identified key threats to information security as including the use of technology 'to carry out acts of aggression aimed at the violation of sovereignty, security and territorial integrity of states'; 'to interfere in the internal affairs of states' or to disseminate 'information that harms [the] political and socio-economic systems, spiritual, moral and cultural environment of other states'.

The Moscow-based international software security group Kasperky Lab and the state-owned China Cyber Security Company signed a strategic co-operation pact at the second, China-sponsored World Internet Conference in Wuzhen, Zhejiang province in December. This co-operation is aimed at an unnamed state actor that has mounted sophisticated attacks against both countries.

China's focus on becoming the dominant power in the western Pacific leaves room for an active role by Russia. As reported in Japan, in 2014 Russia and China had more-or-less equally provoked its air force to scramble fighter jets in what turned out to be an unprecedentedly high number of incidents. The two countries were at it again in 2015, carrying out joint naval and air force exercises over the Sea of Japan from 20-28 August. And Russia finally agreed to sell twenty-four Su-35 fighters to China over three years, with delivery starting in late 2016, despite reported Russian concerns over the risk of reverse engineering. 


\section{Fairly Friendly Giants}

The current Chinese leadership has made some effort to prioritise relations with India, which historically have never been too friendly. Li Keqiang went there on his first overseas visit in 2013, and Modi's 2015 tour in China was reciprocating a 2014 visit by Xi. India, like Pakistan, agreed to join the China-led SCO in 2015. Bilateral trade remained at a healthy US $\$ 70$ billion in 2014 figures, though the balance was very much in China's favour, with a surplus of around US $\$ 48$ billion.

Modi, like Xi a nationalist with a forceful personality, visited China in May. A border incursion into still-disputed territory by Chinese troops had marred Xi's 2014 visit to India, and Modi had annoyed his hosts by making a joint statement with President Obama in January, declaring the importance of freedom of navigation in the South China Sea. China is wary of India's objectives as a rising naval power, and India is cautious of China's motives in the Indian Ocean, including through the OBOR Initiative. Xi Jinping had moreover just concluded an oft-delayed visit to Pakistan in April, agreeing to a massive and much-needed US $\$ 46$ billion investment package. China also announced that it would sell Pakistan eight submarines, more than doubling its existing fleet.

Both China and India seem to want a more positive dynamic. Xi started his visit in Gujarat, Modi's home state, and Modi landed in Xi's hometown of Xi'an, with Xi flying there to meet him, a privilege never accorded to any other VIP. This venue was historically relevant as well as personal; 
Xi'an, or Chang'an, was the dynastic capital of China and the starting point for the Buddhist monk Xuanzang's famous seventh-century pilgrimage to India to collect Buddhist sutras and relics to nurture Chinese Buddhism. For his part, Modi went home with twenty-one trade and investment deals in his pocket worth around US $\$ 22$ billion. This is clearly better than nothing, but substance has yet to catch up with diplomacy.

\section{Across the Pacific}

In February 2015, China publically confirmed that Xi would make a state visit to the US in September, when he would also visit the United Nations for the annual Leaders' Week. The unusually early announcement was perhaps intended to provide some ballast for this unstable relationship through the year.

The main causes of bilateral friction were not new. They included cyber espionage: in June 2015, the US Office of Personnel Management (OPM) revealed it had been the target of a data breach involving the records of millions of American citizens. The Washington Post called it 'one of the most devastating breaches of US government data in history'. Many in the US suspected China was behind it, which China denied. On the eve of Xi's visit, the Chinese government announced it had arrested the hackers involved. The Post observed that this might have been, as some US officials speculated, simply part of 'an effort to lessen tensions with Washington' ahead of the visit.

Another important source of tension was China's 'island building' in the South China Sea-what US Admiral Harry Harris, Commander of the United States Pacific Command, described in a speech in Canberra in 2015 as a 'Great Wall of Sand'. (See the China Story Yearbook 2014: Shared Destiny, Forum 'Sandcastles in the South China Sea', pp.78-81.) The Pentagon takes a dim view of China's attempts to increase its strategic reach by creating what are in effect stationary aircraft carriers for the PLA, on land features claimed by other states.

Few expected Xi's visit to break much ground. The two sides had clearly done a lot of work to agree on the boundaries of the scope of State- 
Concern over the construction of artificial islands in the disputed waters of the South China by the PRC intensified in 2015. Separate reports by the Pentagon and the Washington DCbased Asia Maritime Transparency Initiative indicated that work on seven islands had either been completed or was well advanced by May 2015. In January 2016, the Chinese completed an airstrip on Fiery Cross Reef-an established reef that the Chinese have converted into an artificial island that is long enough to land the PLA's heaviest bombers and air transports. In total, between early 2014 and mid-2015, Chinese dredgers raised roughly twelve square kilometres of land above the waves, an area about the size of Heathrow Airport. According to the Pentagon, over the past forty-five years other claimants (which include the Philippines and Vietnam) have reclaimed only about one hundred acres of land in the area.

This disparity, and the PLA's apparent determination to assert Chinese sovereignty over both the airspace and sea around its new islands came under increasing fire by senior US officials in the first half of the year, culminating in a speech by US Secretary of Defense Ashton Carter at the 30 May Shangri-La Dialogue in Singapore. Carter called for 'a lasting halt' to island building, singled out China for going 'much further and much faster than [any other claimant]', and said that the US military would not be deterred from sailing or flying where it wished.

Carter's remarks foreshadowed the mutual tension that built over the summer and into the early fall. US Pentagon officials also dropped frequent hints that the US was examining options for 'freedom of navigation operations' (FONOP) in the waters around the new islands. FONOPs, in which US ships sail through contested waters, are intended to challenge what the US sees as excessive or illegal territorial claims.

Under the United Nation Convention on the Law of the Sea (UNCLOS), sovereign states are entitled to 'territorial waters' extending twenty-two kilometres from their coastline. Foreign military vessels are permitted 'innocent passage' through territorial waters, but they must refrain from any activity 'prejudicial to [the coastal state's] peace, good order or ... security'. Although

supported espionage, even if they remain hazy, and though they did not issue a fully joint text on the subject, there was substantial agreement in their separate publications. As for the Pacific, Xi stated China had no intention to militarise the South China Sea area. Yet Xi's definition of 'militarisation' appears limited to the display of offensive capability; China claims it is acting to enhance capacity for national defence, as well as providing global goods in the form of crisis management capacity.

The US Freedom of Navigation Operations in the Spratly Islands have highlighted the tensions surrounding China's efforts to become de facto leader of a region where the US has long been the dominant power (see Information Window 'South China Sea and the US FONOP' above). Nonetheless, neither side wants conflict and, despite outbursts of official rhetoric and the occasional sensational headline, extensive policy co-operation creates multiple avenues for dialogue, reducing the risks in times of crisis. 
UNCLOS does not require warships making an innocent passage to provide advance notice, Chinese law does, a position that the PLA Navy seeks to enforce.

Although the South China Sea was on the agenda of a summit meeting between Barack Obama and Xi Jinping at the White House in late September, they failed to reach an understanding. In October, the USS Lassen, a US Navy guided missile destroyer, sailed within twenty-two kilometres of Subi Reef, one of the newly built artificial islands, in

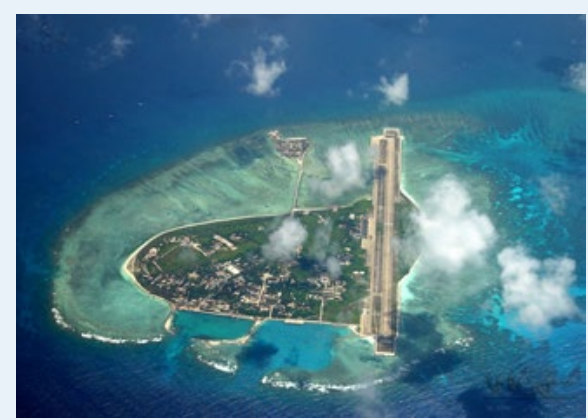

China's 'island building' in the South China Sea Photo: guancha.cn what anonymous Pentagon sources described as both an innocent passage and a FONOP. The Lassen did not provide prior notice of its passage. Some observers wondered whether the US, in claiming innocent passage, had inadvertently bestowed implicit recognition upon China's territorial claim.

A letter from Ashton Carter to US Senator John McCain on 22 December finally put the rumours to rest by clarifying that the Lassen's passage was meant to challenge what the US saw as China's illegal attempts to restrict freedom of navigation by requiring prior notice for innocent passage. It was not, he stressed, an indication that the US had taken a position 'on which nation has the superior sovereignty claims over each land feature in the Spratly Islands. Thus, the operation did not challenge any country's claims of sovereignty over land features, as that is not the purpose or function of a FONOP.'

Chinese official reaction to the Lassen operation took little note of these distinctions. State media described the US as 'irresponsible' and 'reckless', and Chinese Foreign Ministry spokesman Lu Kang 陆康 said the US should not 'make a fool out of themselves in trying to be smart'.

\section{Diplomacy in North East Asia}

In 2014, Xi shook Japanese Prime Minister Shinzō Abe’s hand. But in 2015, there was also much fist shaking. The official Xinhua News Agency described as 'insincere' the statement by Abe on the end of WWII in August, in which he expressed 'remorse' and pledged that Japan would 'never again resort to any form of the threat or use of force as a means of settling international disputes' and would 'respect the right of self-determination of all peoples throughout the world'. However, he stopped short of issuing a clear apology.

For its part, at the military parade commemorating Japan's surrender, China showcased its new Dong-Feng 26 (DF-26, 东风-26) missile, also known as the 'Guam Killer' for its ability to reach the island chain from Chinese territory. China, meanwhile, continued to patrol the seas 


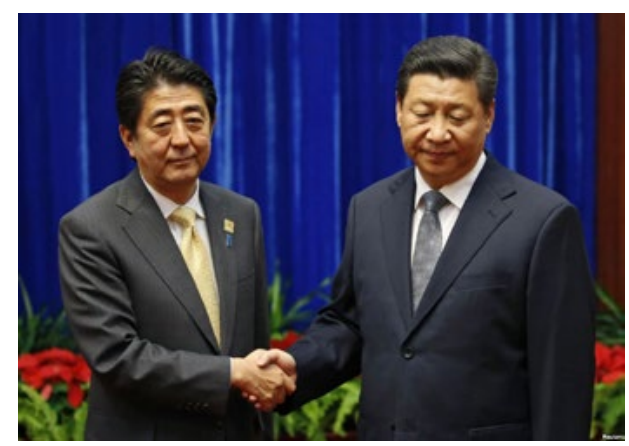

Abe and Xi shake hands at the APEC meeting in Beijing Photo: gdb.voanews.com around the Diaoyu/Senkaku Islands, which both sides claim, and Japan continued to scramble fighter jets in high numbers to prevent possible incursions by Chinese planes.

At the same time, there have been positive developments. Japan's National Security Advisor Shotaro Yachi 谷内 正太郎 and Chinese State Councillor for Foreign Affairs Yang Jiechi 杨洁箎 co-chaired the first China-Japan High Level Political Dialogue in Beijing in July, affirming and acknowledging the 'momentum' for improvement in bilateral relations.

Yang made a reciprocal visit to Japan in October where he also met with Abe, laying the groundwork for a possible Leaders' Summit. Yet the passage of a new security law by the Japanese Diet in July and Japanese protests to UNESCO in October over the inclusion of documents on the Nanjing Massacre in its 'Memory of the World' program restrained the pace of what is already a very slow thaw in relations.

Despite having resolved none of the issues that had blocked such a meeting since 2012, Li Keqiang met his Korean and Japanese counterparts for the first time in three years in Seoul on 1 November, signalling that China wants to continue dialogue, even if the underlying problems are tricky to deal with.

As for North Korea, Beijing remains concerned about Pyongyang's nuclear program and supports sanctions as long as North Korea continues to violate UN resolutions. Yet Politburo Standing Committee member Liu Yunshan 刘云山 visited Pyongyang in October for a parade

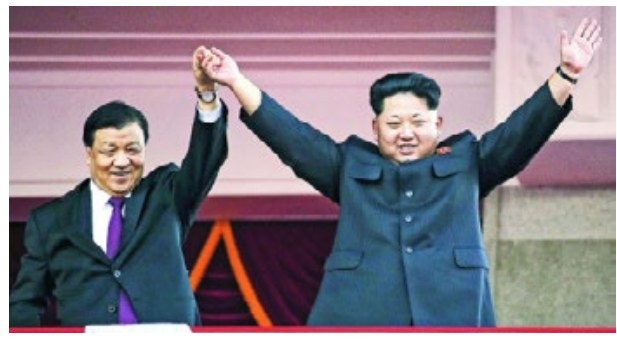

Liu Yunshan in North Korea Photo: mingpaocanada.com 
marking the seventieth anniversary of the Workers' Party, carrying a supportive message from Xi Jinping and prompting speculation of a more senior visit.

Speculation cooled when the Moranbong 'girl' band, whose members are apparently hand picked by Kim Jong-un, visited Beijing two months later but then left suddenly, without performing and without explanation. This might have been because Xi Jinping decided not to attend the performance after Kim announced, only days earlier, that North Korea was 'ready to detonate a self-reliant A-bomb and H-bomb'.

Rumours also circulated that the band had departed after a stand off regarding a song declaring Chairman Mao 'the greatest on earth' but 'Great Leader Kim' the 'greatest in the universe'. Either way, relations continued to cool following a reported test of the hydrogen bomb at the start of 2016, and it is not clear how ties might recover. Since 2013, Xi Jinping has held six summits with South Korea's President Park Geun-hye. He has never met Kim Jong-un.

\section{... and in South East Asia}

$\mathrm{Xi}$ and Li both visited the region, an important part of the 'Maritime Silk Road'. But China's continued, enthusiastic pursuit of island building in contested waters and dismissal of regional concerns meant that diplomatic gestures such as Xi's visit to Vietnam in November, the first by a Chinese president in ten years, were

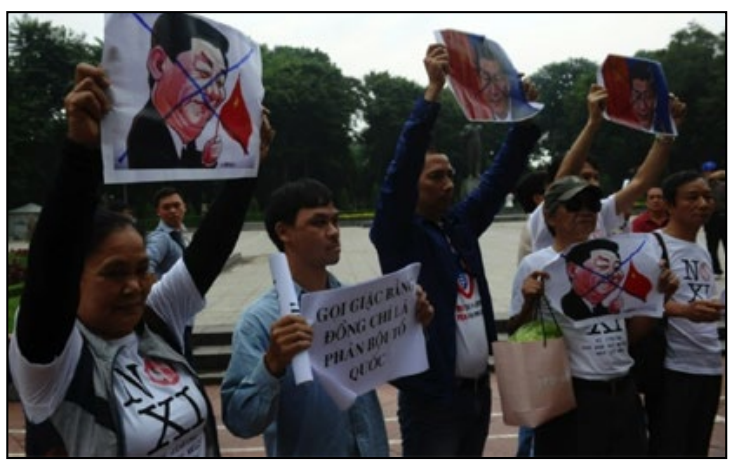

Vietnamese protesters greet Xi's arrival Source: ndtv.com not universally well received. The Vietnamese government, apparently divided between pro-US and pro-China factions, brutally suppressed some of the protests. 


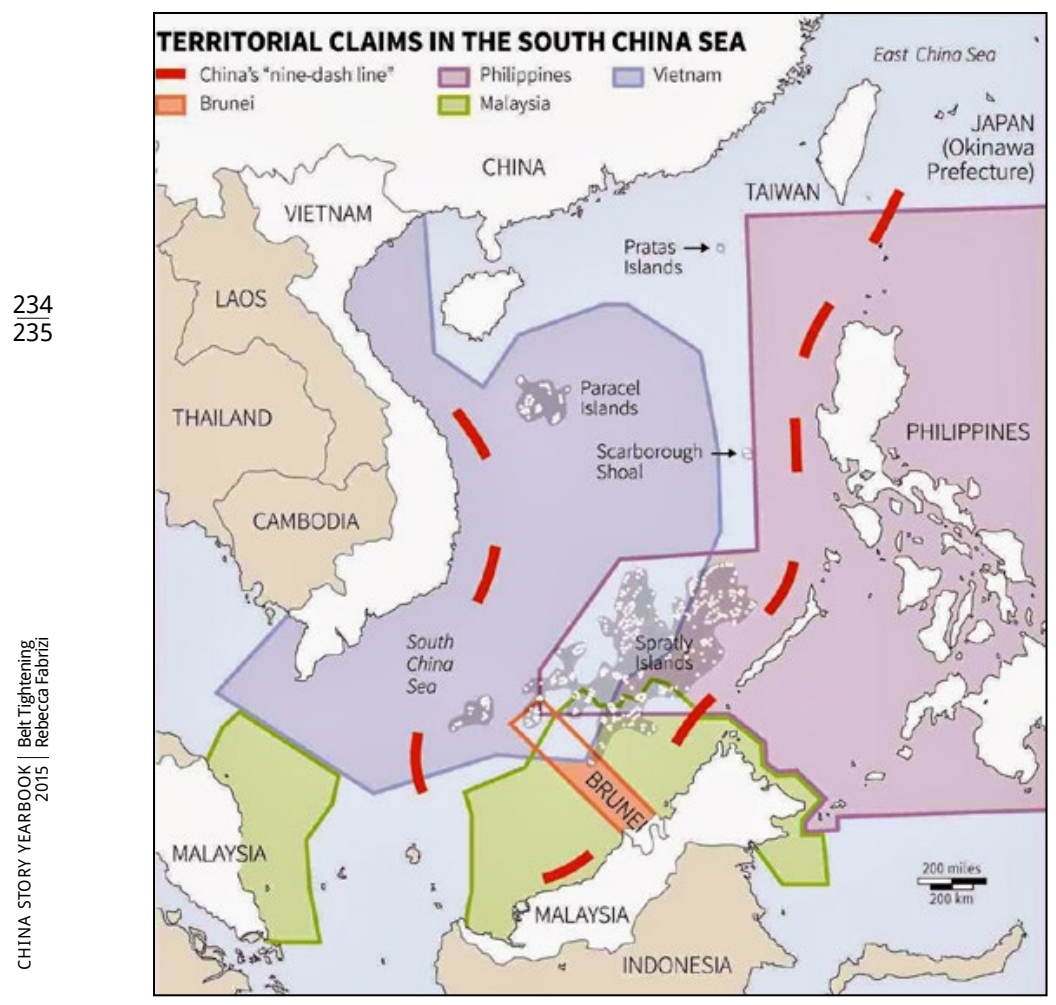

In June, the Chinese Foreign Ministry announced that it would stop reclaiming land in the South China Sea. At the same time, it said it would continue to construct facilities on the islands it had already built-some 1,170 hectares of land in total, according to Pentagon estimates.

By September, China had also completed construction of its first airstrip there, on Fiery Cross Reef. There are four other airstrips in the region, built by Vietnam in 1976, the Philippines in 1978, Malaysia in 1983, and Taiwan in 2006. The Chinese government has accused its critics of a double standard, given that other claimants to the Spratly Islands have also built islands-although only amounting in total to five percent of all the reclaimed land there, with China responsible for ninety-five percent. China's new airstrip, at 3,000 metres, is more than twice as long as any of the others.

In November 2015, an arbitral tribunal facilitated by the Permanent Court of Arbitration (PCA) in The Hague decided that it did have jurisdiction to hear a case brought by the Philippines contesting various Chinese claims, including the nine-dashed line by which China demarcates its 


\section{THE CHINESE ARMED FORCES IN 2015,} by Rebecca Fabrizi

China's military development continued apace in 2015, with a defence budget of approximately US\$215 billion, a 10.1 percent increase from 2014 . This was the second largest after the US, at US\$596 billion, and way ahead of Saudi Arabia, at US $\$ 87.2$ billion. The expansion is intended to advance the modernisation of China's military, especially the navy and air force, which have traditionally lagged way behind land forces, as well as to fund the development of new weapons systems. China's new Dong-feng 26 (DF-26, 东风-26) anti-ship ballistic missiles were among new hardware revealed th the military parade on 3 September.

China released a military strategy paper in 2015, providing some broad insights into its strategic goals, including '... making the military strong as part of the Chinese Dream'. Key tasks were to safeguard territorial interests and the unity of the motherland; protect against separatism; safeguard China's overseas interests; maintain strategic deterrence; and provide overall support to the Chinese Communist Party.

China's military parade on 3 September showcased the new DF-26, or 'Guam Killer' missile. At the end of December, the Ministry of Defence confirmed that China had constructed its first domestic-built aircraft carrier. Other modernisation efforts have focused on cyber and counter-space capabilities (the latter focuses on the use of satellites in warfare and includes the development of 'directed-energy weaponry' and satellite jamming technology).

The biggest story in the Chinese military in 2014 and 2015 was the unprecedented crackdown on corruption at senior levels. The campaign has felled two of the most powerful officers of recent times, Xu Caihou 徐才厚 and Guo Boxiong 郭伯雄, both former vice chairmen of the Central Military Commission (CMC) 中央军事委员会. Xu died in 2015. His case had been dropped in 2014 when it was clear that his failing health was already a death sentence. Guo, who was the more senior and who may have accumulated even more dirty money than $\mathrm{Xu}$, was accused of bribery in July. On 6 July, the People's Daily reported that more than 200 officers of lieutenant-colonel rank and above had been punished in 2013 and 2014 for corruption.

China's armed forces serve the Communist Party. Under the previous president Hu Jintao, the control of the civilian leadership over the army was seen as weak. The world got a glimpse of this weakness when the PLA tested its first stealth fighter on the day of a visit by US Defense Secretary Robert Gates in 2011 apparently without Hu's knowledge. This stunning display of the military taking the initiative on foreign policy came just one week before Hu's State visit to the United States.

In December, Xi completely overhauled the command structure, asserting and consolidating control by downgrading the previously powerful four PLA functional headquarters to departments of the Central Military Commission (CMC). The navy and air force got their own commands, no longer subordinate to the vastly more numerous land forces. There were new commands for space and cyber-warfare, as well as ballistic and cruise missiles. A new joint command, meanwhile, followed the US model. The number of regional commands was reduced from seven to five to increase central control. Xi repeated his commitment to reduce military personnel by 300,000 , to two million. In what appeared to be a final confirmation that he had secured total control over the armed forces, in 2016, Xi emerged as Commander-in-Chief 总指 挥, a title never before used in the PRC. 


\section{XI'S UK VISIT, by Rebecca Fabrizi}

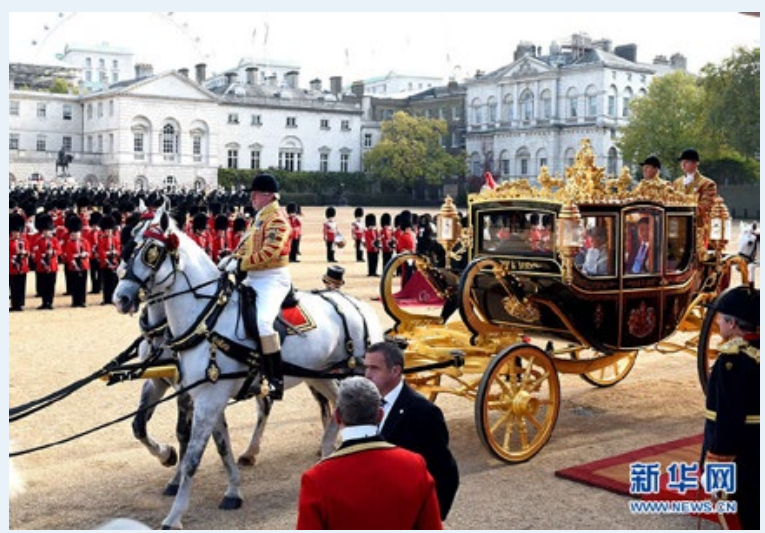

Xi Jinping attends the official welcoming ceremony in Horse Guards Parade Photo: news.xinhuanet.com

At the end of a day of pageantry during Xi's visit to the UK in mid-October, the lavish banquet at Buckingham Palace wrapped up with a rendition by the Countess of Wessex's String Orchestra of 'Nobody Does It Better', the theme song from the The Spy Who Loved Me, a James Bond flick about two stolen nuclear submarines. The two countries had earlier announced that China would take a one-third stake in the $£ 18$ billion Hinkley Point $C$ nuclear power plant project.

Former prime minister Cameron had been hailing the 'golden era' 黄金时代 in SinoBritish relations ever since his 2015 re-election. British policy aims to secure London's primacy in both international trading in the RMB and Chinese inward investment into Europe. But David Cameron and former chancellor George Osborne annoyed many of the UK's traditional allies as well as domestic critics who believe Britain had abandoned universal values in favour of hard cash, despite there being no evidence that the UK's human rights policy towards China had changed. Steve Hilton, David Cameron's former advisor, called Xi's visit 'one of the worst national humiliations we've seen since we went cap in hand to the IMF [International Monetary Fund] in the 1970s'.

Chinese state media, meanwhile, joyously propagated images of $\mathrm{Xi}$ and his wife Peng Liyuan enjoying a traditional state visit. 'No institution does pomp and pageantry quite as well as the British royals, and probably no institution appreciates it as much as the modern Communist Party of China,' observed The Financial Times. Britain's role in China's 'century of humiliation' was overlooked in favour of the rhetoric of 'win-win co-operation' 共赢 and enthusiastic praise for British culture. Even the nationalistic Global Times, which in 2013 called Cameron's overtures insincere and the UK nothing more than 'an old country apt for travel and study', railed against any suggestions that the 'golden age' was built on inequity. It characterised such a view as mere 'sour grapes'. 
claim to sovereignty over all of the South China Sea's land features on the map. China refuses to accept that this case has any legal basis, and doesn't recognise the authority of the PCA. The tribunal's decision, however, makes quite clear that the case can be heard, whether or not both parties agree to engage. China has always been deliberately vague about the legal basis of its own claims, preferring to assert 'historical rights'. There is no basis under the UN Convention on the Law Of the Sea (UNCLOS) for a nation to claim territorial rights based on islands built on low-tide elevations unless they are on its continental shelf. By building and populating relatively large islands, China may be hoping to create a new precedent in its own interests.

China called the US FONOPS (see Information Window 'South China Sea and the US FONOP', pp.230-231) 'illegal' (under Chinese domestic law rather than UNCLOS) and a 'threat to China's sovereignty and security'. Other South China Sea claimant states kept quiet, failing to take take a unified position. China has successfully avoided multilateral discussion of the matter, though they appear more inclined to acknowledge that a solution will require discussion with ASEAN.

\section{Global Attitudes}

Most countries struggled to find a consistent and constructive China policy that would serve their policy interests in 2015. The then prime minister of Australia Tony Abbott crudely summed up a common (if rarely vocalised) attitude when he told German Chancellor Angela Merkel that Australians viewed China with 'fear and greed'. For China's neighbours, balancing independence and beneficial economic ties with China is a challenge, one thrown into relief by the OBOR Initiative. Nations less concerned by China as a potential security threat, such as in more distant Europe are nonetheless perturbed by ever-increasing restrictions on civil liberties. How to deal with a China that is rich, influential, yet not showing any trend towards becoming a liberal democracy is seen to violate human rights and is one of the most pressing diplomatic questions for the US and its allies. 
The United Kingdom took a bold and opportunistic stance under the initiative of former chancellor George Osborne to court China, becoming its 'best friend in Europe'. The UK was the first European country to ignore US lobbying and state its intention to become a founding member of the AIIB. Xi described the UK's position as 'visionary' when he visited in October, although many commentators described it as embarrassing, and the US accused it of 'constant accommodation'.

Britain has certainly taken a risk in alienating traditional allies: investment from China might be growing but it is still small at around three percent of Foreign Direct Investment (FDI) stock, as opposed to twenty-seven percent from the US, and China's economic and political future is uncertain. However, it was interesting to see a new diplomatic approach, one with less hedging, working with China in pursuit of UK interests where possible, and leaving space to defend universal values where appropriate. How best to interact with China on the international stage will depend on how China's domestic struggles play out. It is too early to tell.

\section{Afterword}

In July 2016, an arbitral tribunal at the Permanent Court of Arbitration in The Hague issued a ruling in Manila's case against claims made by Beijing in the South China Sea. The tribunal was established according to UNCLOS provisions and its ruling was final and binding. The ruling dismissed most of Beijing's claims, including to 'historic rights' and any validity of the nine-dashed line. It also found that Beijing had violated the traditional fishing rights of Filipinos around Scarborough Shoal, and the sovereign rights of the Philippines over living and non-living resources.

China has angrily refused to recognise the validity of the court or its ruling. Indeed, there is no enforcement mechanism. China has also conducted a vigorous diplomatic campaign to reduce international pressure to abide by the ruling. President Duterte of the Philippines has called for bilateral talks. China announced that a senior officials meeting with ASEAN on 16 August had achieved consensus on achieving a draft Code of Conduct by mid-2017. 


\section{IN DC, by Rebecca Fabrizi}

Xi Jinping visited the US from 22-28 September 2015. He kicked off with two days of speeches and meetings with tech executives in Seattlean opportunity to stress the two countries' strong commercial ties, but also to reassure a powerful sector rattled by the implications of China's expanding national security regulations. After his first state visit to Washington DC, from 24-25 September, where President Obama hosted meetings and a state dinner at the White House, he spent several days at the United Nations in New York.

The visit was not widely expected to be a success. It coincided with the growing scandal

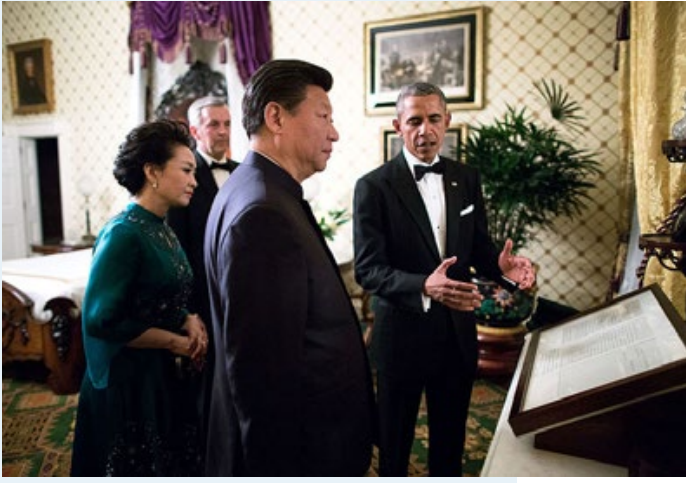

Peng Liyuan, Xi Jinping, and Barack Obama in the Lincoln Bedroom in the White House

Photo: Peter Souza, Flickr over a cyber attack on the Office for Personnel Management, in which as many as twenty million records were stolen, making it the largest breach of government data in US history, and which US government sources attributed to China. There were other sources of tension as well. The turbulence in China's stock market over the preceding months had sharply reduced confidence in China's economic management. And the US had been criticising China's island-building in the South China Sea for several months, to Beijing's acute irritation.

In the end, things went slightly better than expected. Intense negotiation on cyber security in the weeks preceding the visit resulted in some agreed-on, if weak, language on the subject. Both sides agreed not to 'conduct or knowingly-support' commercial espionage, though China has consistently denied doing this anyway. The difference between commercial and national security espionage remained undefined. Given sweeping definitions of national security in China this leaves an expansive grey area, encompassing the various commercial sectors described as 'core' national interests. However, the agreement provided a basis for further discussion. Both sides committed to a ministeriallevel, multi-agency dialogue twice a year.

With regard to climate change, China and the US had made headlines ten months previously with an agreement that put Australia to shame on the eve of the Brisbane G20 Summit. During this visit, they built on this agreement, releasing a joint vision statement for the UN Conference on climate change, COP21 in Paris (30 November-12 December 2015). Co-operation between two of the largest emitters of carbon dioxide was fantastic news for COP21, and demonstrated China's commitment to making a substantive contribution to global governance.

The two Presidents addressed regional security in their joint press conference, including the South China Sea. Xi denied any intention to militarise the Spratly Islands, and said that China supported freedom of navigation and overflight in accordance with international law. Perhaps his words, at odds with China's actions ever since, were intended to blame the US for militarising the area, and bolster the idea that all China does is defend its sovereign interests. More meaningful was an agreement on handling air-to-air encounters, of which there had been several through 2014 and 2015, including a reported near miss by only ten metres. 
This text is taken from China Story Yearbook 2015: Pollution, edited by Gloria Davies, Jeremy Goldkorn and Luigi Tomba, published 2016 by ANU Press, The Australian National University, Canberra, Australia. 